\title{
MENELUSURI LATAR HISTORIS TURUNNYA ALQURAN DAN PROSES PEMBENTUKAN TATANAN MASYARAKAT ISLAM
}

\author{
Irma Riyani \\ Dosen Jurusan Ilmu Alquran dan Tafsir,Fakultas Ushuluddin \\ UIN Sunan Gunung Djati Bandung \\ J1. A.H. Nasution 105 Cibiru Bandung 40614, Indonesia. \\ E-mail: riyani.ime@gmail.com
}

\begin{abstract}
This article explores the history of Qur'anic revelation to understand how the messages of the Quran established the new community in the seventh Century. This article is based on the fact that the Qur'an was being revealed portion by portion within the duration of \pm 23 years in Arabia: responding to the situation and answering to the need of the context at that time. Many of the messages of the Quran was the rebuttal of many previous (Jahiliyya) social norms. In fact, many of Qur'anic verses are directed not only to reform the already established Jahiliyya social norms but also to change radically of those norms and replace those with new norms that enlighting and liberating. This article aims to consider socio-historical contextan important aspect in understanding Qur'anic verses especially in relation to modern social situations.
\end{abstract}

Keywords:

Alquran; Muslim community; historis; reality.

\begin{abstract}
Abstrak
Tulisan ini berusaha untuk menelusuri kembali seperti apa sejarah penurunan Alquranuntuk mengetahui bagaimana pesan-pesan Alquran tersebut mampu membangun tatanan sosial baru berdasarkan petunjuk Alquran. Tulisan ini dilandaskan pada kenyataan bahwa Alquran diturunkan secara berangsur-angsur selama \pm 23 tahun kepada masyarakat Arab pada waktu itu, mengomentari keadaan dan peristiwa-peristiwa yang mereka alami bahkan menjawab pertanyaan-pertanyaan dan permasalahan yang mereka hadapi. Banyak di antara pesan-pesan Alquran bersifat bantahan yang nyata atas norma-norma sosial yang diberlakukan masyarakat Jahiliyyah. Isi Alquran bukan hanya mereformasi tatanan masyarakat yang ada tetapi bahkan merevolusi konsep-konsep yang sudah baku dan menggantinya dengan konsep baru yang mencerahkan dan membebaskan. Tulisan ini diharapkan dapat mengembalikan kita pada pemahaman menyeluruh tentang makna dasar Islam datang dan mampu secara lebih bijak memahami kondisi masyarakat modern dengan berkaca pada tujuan penurunan Alquran bagi kehidupan umat Islam.
\end{abstract}

Kata Kunci:

Alquran; masyarakat Muslim; historis; realitas.

\section{A. PENDAHULUAN}

Alquran merupakan sumber utama bagi umat Islam yang berfungsi sebagai petunjuk bagi kehidupan di dunia untuk meraih kehidupan di akhirat.Karena fungsinya tersebut, maka usaha untuk mengkaji dan memahami Alquran menjadi persoalan yang sangat penting sehingga pesan-pesan yang terkandung di dalamnya dapat diterima sekaligus dapat dilaksanakan.

Selain itu, sudah merupakan suatu keyakinan yang melekat di kalangan umat Islam bahwa Alquran adalah mukjizat Nabi
Muhammad Saw.yang kekal dan ajaranajarannya bersifat universal. Hal tersebut didukung pula oleh keyakinan bahwa Islam adalah agama terakhir yang menyempurnakan agama-agama sebelumnya. Karena keyakinan tersebut, maka Alquran haruslah mampu menjawab persoalan-persoalan yang dihadapi oleh masyarakat muslim kapanpun dan dimanapun, serta sejalan dengan perubahanperubahan yang dialaminya.

Tetapi, apakah memang kita sudah benarbenar memahami ajaran Alquran yang bersifat universal tersebut dalam kehidupan kita 
sekarang ini.Kehidupan modern dengan segala perubahannya yang cepat dalam berbagai bidang kehidupan; sosial, ekonomi, politik, dan bahkan dalam bidang pemikiran. Dan apakah konsepsi-konsepsi Alquran masih dapat dipergunakan dalam mencari solusi dan terapi kegalauan sosial yang diakibatkan modernitas dan perubahan sosial tersebut?

Kalau kita telusuri sejarah turunnya Alquran, maka kita akan melihat bahwa teks Alquran terbentuk dalam rentang waktu lebih dari dua puluh tahun sebagai respon terhadap persoalan-persoalan sosial yang dihadapi masyarakat Arab pada masanya. Sebab itulah, maka dalam memahami Alquran tidak bisa dilepaskan begitu saja dengan sejarah dan tradisi saat Alquran diturunkan, untuk mengetahui pesan dasar dari maksud tersebut.

Alquran diturunkan secara berangsurangsur selama \pm 23 tahun kepada masyarakat Arab pada waktu itu, mengomentari keadaan dan peristiwa-peristiwa yang mereka alami bahkan menjawab pertanyaan-pertanyaan dan permasalahan yang mereka hadapi. Banyak di antara pesan-pesan Alquran bersifat bantahan yang nyata atas norma-norma sosial yang diberlakukan masyarakat Jahiliyyah. Isi Alquran bukan hanya mereformasi tatanan masyarakat yang ada tetapi bahkan merevolusi konsep-konsep yang sudah baku dan menggantinya dengan konsep baru yang mencerahkan dan membebaskan.

Tulisan ini berusaha untuk menelusuri kembali seperti apa sejarah penurunan Alquran dan bagaimana pesan-pesan Alquran tersebut mampu membangun tatanan sosial baru berdasarkan petunjuk Alquran. Tulisan ini diharapkan dapat mengembalikan kita pada pemahaman menyeluruh tentang makna dasar Islam datang dan mampu secara lebih bijak memahami kondisi masyarakat modern dengan berkaca pada tujuan penurunan Alquran bagi kehidupan umat Islam.

\section{B. HASIL DAN PEMBAHASAN}

\section{Tujuan Kehadiran Alquran}

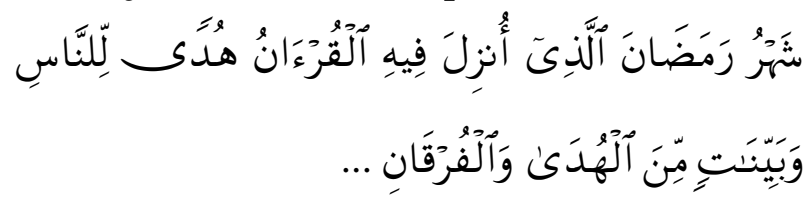

Bulan Ramadhan, bulan yang di dalamnya diturunkan (permulaan) Al Quran sebagai petunjuk bagi manusia dan penjelasanpenjelasan mengenai petunjuk itu dan pembeda (antara yang hak dan yang bathil)... (QS. 2: 185)

Alquran diturunkan pada masyarakat Arab saat itu adalah untuk meluruskan patologi sosial masyarakat Arab dan sebagai kitab petunjuk bagi seluruh umat manusia. Tata nilai masyarakat Arab sudah sedemikian parahnya sehingga perlu adanya kitab petunjuk untuk meluruskan kondisi tersebut. Tata nilai dan perubahan yang dibawa oleh Alquran mampu memberikan pengaruh yang cukup mendalam pada diri orang Arab sehingga Islam mampu membangun tatanan baru masyarakat yang kokoh berlandaskan Alquran. Politheisme dan paganisme dirubah menjadi monotheisme, fanatik kesukuan dirubah menjadi persamaan dan persaudaraan, penindasan menjadi keadilan sosial.

Tantangan dan patologi sosial selalu ada dan selalu akan muncul mengiringi perjalanan hidup manusia. Hal ini berkaitan erat dengan potensi yang ada dalam diri manusia yaitu potensi destruktif dan konstruktif.Sebab itu, manusia tidak boleh ditinggalkan tanpa petunjuk dan harus terus dibimbing. Dan Alquranakan selalu menjadi kitab petunjuk dalam membimbing manusia di mana pun dan kapan pun terjadi patologi sosial.

Alquran adalah suatu ajaran yang berkepentingan terutama untuk menghasilkan sikap moral yang benar bagi tindakan manusia.Tindakan yang benar, apakah itu tindakan politik keagamaan ataupun sosial, dipandang Alquran sebagai ibadah (pengabdian terhadap Allah).Karena itu, Alquran mengutamakan semua penekanan moral dan faktor-faktor psikologis yang melahirkan kerangka berfikir yang benar bagi 
tindakan. ${ }^{1}$ Hal ini sesuai dengan tujuan utama Alquran yakni menegakan sebuah tata aturan masyarakat yang adil, berdasarkan etika dan dapat bertahan di muka bumi ini. ${ }^{2}$

\section{Latar Historis Turunnya Alquran}
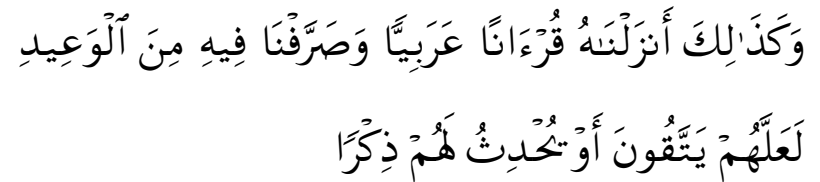

Dan Demikianlah kami menurunkan Al Quran dalam bahasa Arab, dan kami Telah menerangkan dengan berulang kali, di dalamnya sebahagian dari ancaman, agar mereka bertakwa atau (agar) Al Quran itu menimbulkan pengajaran bagi mereka.(QS. Thāha [20]: 113)

Bermula dari sebuah kawasan yang bernama jazirah Arabia 15 abad yang lalu manusia Muhammad lahir sebagai pengemban risalah dari Allah Swt. Jazirah Arabia terletak di Asia Barat Daya, daerahnya terbentang luas dalam bentuk padang pasir dengan daerah perbatasan di sebelah Utara adalah negeri Syam, sebelah Timur dibatasi oleh Teluk Persi dan di sebelah Selatan dibatasi oleh dua lautan yaitu laut Hindia dan laut Merah. ${ }^{3}$

Jazirah Arabia terbagi menjadi dua bagian penting yaitu Arabia Utara dan Arabia Selatan.Arabia Utara adalah penduduk yang menetap pada suatu perkampungan di daerah Yaman, Hadramaut, dan pemukiman seputar pantai.Kehidupan mereka lebih maju karena mereka menetap (tidak berpindah-pindah) sehingga memudahkan untuk membangun sebuah peradaban.Bahasa yang mereka gunakan pun lebih bagus dan lebih teratur. Sementara itu Arabia Selatan ditempati oleh masyarakat yang hidupnya berpindah-pindah (nomaden) mendiami daerah Hijaz dan Najd. ${ }^{4}$ Arabia dengan padang pasirnya merupakan daerah panas dan kering. Keadaan ini

1 Fazlur Rahman, Islam, terj. Ahsin Muhammad (Bandung: Pustaka, 1994), 354.

2 Fazlur Rahman, Tema-tema Pokok al-Qur'an, terj. Anas Mahyudin (Bandung: Pustaka, 1996), 54.

${ }^{3}$ Ahmad Amin, Fajr al-Islām, (Beirut: Dār al-Fikr, $\mathrm{tt}), 1$

${ }^{4}$ Philip K. Hitti, History of The Arab, (New York: Macmillan Student, 1970), 30. berimplikasi pada pola dan sistem kehidupan yang mereka jalani.

Orang-orang badāwah adalah orang-orang pedalaman yang terdiri dari berbagai suku dan kehidupannya selalu berpindah-pindah dari satu tempat ke tempat lain dan tidak pernah menetap pada satu daerah. Mereka selalu mencari daerah yang subur untuk ditempati dan apabila tempat tersebut tidak subur lagi mereka pun pindah untuk mencari tempat lain.

Mereka hidup dalam tenda-tenda yang dirancang sedemikian rupa untuk melindungi diri dari terik sinar matahari di musim panas dan cuaca lembab pada musim dingin. Kendaraan mereka adalah unta yang dipakai untuk barang-barang. Unta memang binatang yang disediakan khusus untuk daerah padang pasir. Binatang ini mampu mengarungi gurun selama 17 hari tanpa minum, karena punya persediaan air dalam tubuhnya. Dan ia pun siap melayani majikannya dengan kekuatan yang dimilikinya.

Karena kehidupan yang selalu berpindahpindah dan selalu mencari daerah yang subur untuk ditempati maka kekuatan fisik sangat penting.Selain itu terbatasnya daerah subur mengakibatkan pertikaian antara suku yang satu dengan suku yang lainnya untuk mendapatkan daerah yang mereka inginkan. Peperangan menjadi hal yang biasa di kalangan mereka, bahkan menjadi ajang olah raga yang digemari. ${ }^{5}$

Masyarakat Arab terdiri dari berbagai suku atau kabilah. Salah satu kabilah yang paling terkenal yang tinggal di kota Makkah adalah suku Quraisy. Mereka terkenal karena kemahirannya dalam berdagang serta karena merekalah yang mengendalikan ka'bah. Ka'bah sebelum Islam, sudah merupakan tempat yang penting sebagai pusat kegiatan keagamaan.Orang-orang berdatangan untuk berziarah setahun sekali dari berbagai pelosok Arab, baik yang jauh maupun yang dekat. ${ }^{6}$ Makkah merupakan kota yang cukup teratur

5 Carl Brockelman, History of Islamic People, (New York: G.P. Putnam's Son, 1944), 5

${ }^{6}$ Montgomeri Watt, Muhammad's Mecca: History in the Quran, (London: Edinburgh University Press, 1982), 38. 
dengan sistem pengaturan kota yang baik. Terlebih pada masa kepemimpinan Qushay telah dibentuk dewan-dewan yang bertanggungjawab pada tugasnya masingmasing. Hijābah adalah bagian pemegang kunci Ka'bah, Siqāyah bagian yang menyediakan air dan makanan untuk para peziarah, Rifälah adalah bagian yang mengumpulkan dana dari si kaya untuk yang miskin, Qamariyyah dan Syamsiyyah adalah bagian yang menetapkan kalender berdasarkan perhitungan bulan dan matahari dan Dār alNadwah adalah balai sidang. ${ }^{7}$

Hampir sebagian besar penduduk Makkah adalah pedagang. Mereka bepergian dalam bentuk kafilah besar melewati daerah-daerah yang dirasa menguntungkan untuk berdagang (QS. al-Quraisy [109]: 1-2). ${ }^{8}$ Selain itu Makkah juga merupakan daerah rute perdagangan antar negara. Dengan dibukanya rute perdagangan ini memungkinkan Arab untuk berhubungan dengan dunia luar seperti Romawi dan Persia yang pada saat itu lebih maju kebudayaannya dibanding Arab.Dari Romawi mereka belajar tentang strategi perang sementara dari Persia belajar berbagai ilmu pengetahuan.

Kehidupan keagamaan penduduk Arabia bervariasi, tetapi yang paling banyak di antara mereka terutama orang Makkah adalah paganisme yakni menyembah berhala.Di bagian Arab pedalaman (badāwah) mereka menganut animisme yaitu percaya kepada kekuatan alam.Mereka menyembah bulan dan bintang, bahkan mereka juga menyembah para leluhurnya. ${ }^{9}$ Di Makkah mereka lebih senang menyembah berhala sebagai tuhannya. Berhala-berhala tersebut mereka beri nama tersendiri, bahkan terkadang masing-masing kabilah memiliki berhala andalan untuk

\footnotetext{
${ }^{7}$ Haikal, Sejarah Hidup Muhammad, (Jakarta: Tintamas, 1984), 35.

${ }^{8}$ Allah menjelaskan dalam QS. Quraisy:

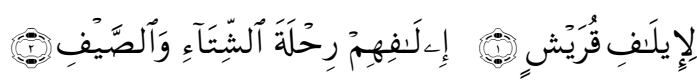

Karena kebiasaan orang-orang Quraisy, (yaitu) kebiasaan mereka bepergian pada musim dingin dan musim panas.

${ }^{9}$ Carl Brokelman,History of Islamic People, 8.
}

disembah. Diantara berhala-berhala mereka adalah Latta, Uzza, Manat, ${ }^{10}$ Qolas, Rudho, Riam, dan lain-lain. ${ }^{11}$ Akan tetapi, selain mereka mempercayai hal-hal tersebut di atas, mereka juga mempercayai adanya Allah, Tuhan atau Dewa sebagai suatu kekuatan transenden yang menguasai kehidupan mereka. Penyembahan mereka terhadap berhala adalah sebagai sarana yang dapat mengantarkan doa mereka kepada Allah tersebut. Selain itu agama-agama yang dianut sebelum Islam juga sudah mengajarkannya, seperti Judaisme, Zoroaster, dan Kristen. ${ }^{12}$ Namun kepercayaan ini tidak begitu populer dan kurang diminati.

Sistem kekeluargaan berdasarkan patriakal (keturunan garis laki-laki) secara langsung dari leluhur hingga ke bawah.Keberadaan seseorang dilihat dari segi kegagahan dan kekuatan dalam menghadapi musuh.Dengan demikian keberadaan perempuan dan anakanak dikesampingkan dan dianggap sebagai warga kelas dua dalam keanggotaan kelompok karena mereka lemah.Pemberian tugas, hak dan status hanya untuk laki-laki dewasa. ${ }^{13}$

Mereka sangat membanggakan sukunya (ashabiyyah) atas suku yang lain dan saling berselisih tentang suku mana yang paling mulia diantara mereka. Selalu mendahulukan

10 Ketiga berhala tersebut diceritakan dalam Alquran surat al-Najm [53]: 19-21:

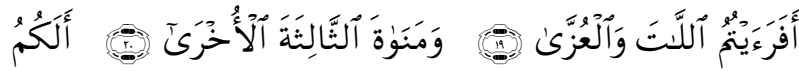

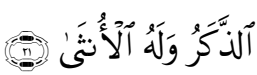

Maka apakah patut kamu (hai orang-orang musyrik) mengaggap Al Lata dan Al Uzza Dan Manah yang ketiga, yang paling terkemudian (sebagai anak perempuan Allah)?Apakah (patut) untuk kamu (anak) laki-laki dan untuk Allah (anak) perempuan? Al Lata, Al Uzza dan Manah adalah nama berhala-berhala yang disembah orang Arab Jahiliyah dan dianggapnya anak-anak perempuan Tuhan.

${ }^{11}$ Ibnu Katsīr.Al-Sirāh Al-Nabawiyyah.(Beirut: Dār al-Fikr, 1990), 71.

12 Ira Lapidus, History of The Islamic Society, (New York: Cambridge University Press, 1993), 7-8; Watt, Muhammad's Mecca: History in the Quran, 32.

${ }^{13}$ Watt, Muhammad's Mecca: History in the Quran,30. 
hawa nafsunya dari akalnya.Peperangan dan balas dendam merupakan hal yang biasa.Berjudi, minum minuman keras dan pelacuran mendapat tempat yang layak dan kegiatan rutin yang tidak bisa dipisahkan dari kehidupan mereka. ${ }^{14}$

Sifat-sifat seperti itulah yang kemudian disebut sebagai jahiliyah, bukan berarti kebodohan dalam bidang intelektual tetapi kebodohan dari petunjuk Ilahi dalam menuntun hidupnya.Dan kepada masyarakat seperti inilah Allah menurunkan Alquran melalui Muhammad sebagai pengemban risalahnya.

\section{Alquran dan Pembentukan Masyarakat Muslim

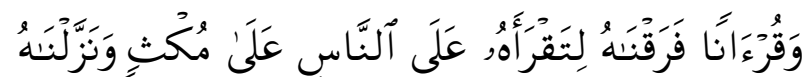

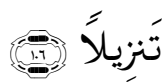

Dan Al Qur'an itu telah Kami turunkan dengan berangsur-angsur agar kamu membacakannya perlahan-lahan kepada manusia dan Kami menurunkannya bagian demi bagian.(QS. Al-Isrā [17]: 106)

Alquran diturunkan secara berangsurangsur mengiringi dakwah Nabi selama \pm 23 Tahun.Pergumulan yang sangat intens ini memberikan implikasi bahwa segala ucapan dan tindakan Nabi dibimbing oleh wahyu.Wahyu tersebut turun memberikan arahan-arahan dan petunjuk serta solusi terhadap permasalahan-permasalahan yang dihadapi oleh masyarakat.Maka dari itu, apabila kita hendak memahami Alquran kita juga harus mengetahui perjalanan sejarah Nabi Muhammad sebagai pembawa risalah Alquran.

Itulah sebabnya umat Islam tidak bisa dipisahkan dari sejarah.Karena sejarah bagi umat Islam sangatlah berarti.Sejarah bagi umat Islam adalah upaya untuk menemukan originalitas ajaran-ajarannya. Untuk memahami ajaran-ajaran Islam, ada dua hal penting yang harus diperhatikan dan dipelajari oleh umat Islam yaitu Alquran sebagai sumber

\footnotetext{
${ }^{14}$ Muhammad al-Ghazāil, Fiqh Sirāh, (Kairo: Matba'ah Hasan, 1988), 25.
}

dan pedoman ajaran-ajaran tersebut dan sunnah Nabi sebagai pembawa risalah.

Pentingnya mempelajari sejarah Islam awal adalah untuk memahami Alquran dari permulaan turunnya untuk mengetahui konteks yang melatari turunnya Alquran tersebut.Selain itu, yang paling penting dari paparan sejarah tersebut adalah agar umat Islam dapat mengambil pelajaran dan hikmah yang terkandung dalam perjalanan sejarah tersebut. Sebagaimana tercantum dalam AlquransuratYüsuf [12] ayat 111:

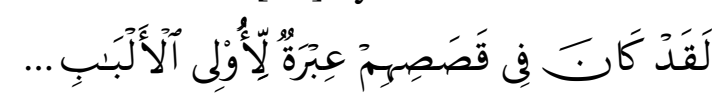

Sesungguhnya pada kisah-kisah mereka itu terdapat pengajaran bagi orang-orang yang mempunyai akal

Sejarah bukan sekedar kisah biasa, tetapi sesuatu yang mengandung pelajaran.Sejarah juga mengandung logika dan memiliki kemampuan menjelaskan (explanatory power) tentang sesuatu hal yang menjadi permasalahan kontemporer.Sejarah mampu memberi petunjuk bagi sikap dan tindakan di masa kini maupun di masa mendatang. ${ }^{15}$

Alquran sebagai kitab pedoman merupakan kitab yang sangat apresiatif dalam mengiringi perjalanan sejarah manusia. Hal tersebut tercermin dalam perbedaan teks Alquran dari segi isi dan gaya bahasa yang dipergunakan antara periode Makkah dan periode Madinah. Periode Makkah (pertama) merupakan pembangunan masyarakat baru sebagai reaksi atas masyarakat lama.Pada periode ini teks Alquran lebih dipusatkan pada pembentukan dasar-dasar yang membangun kesadaran terhadap sesuatu yang sesuai dengan realitas baru yang ingin dibentuk oleh teks.

Perubahan dan pembenahan masyarakat sedikit demi sedikit dilaksanakan. Dalam bidang ekonomi, Makkah, sebagai daerah perdagangan yang ramai, namun di kota ini pun dijumpai eksploitasi terhadap kaum yang lemah (budak-budak dan kuli). Para

15 Dawam Raharjo, "Sepatah Kata tentang Sejarah Muhammad", dalam Sirah Muhammad Rasulullah; Suatu Penafsiran, Fuad Hashem, (Bandung: Mizan, 1996), 17. 
bangsawan Makkah hanya mengkonsentrasikan dirinya dalam upaya untuk menghasilkan keuntungan yang sebesarbesarnya tanpa memperdulikan orang lain. Karena kesenangan mereka menumpuk harta menyebabkan mereka tidak peka terhadap masalah sosial di sekelilingnya seperti kemiskinan dan kelaparan.Alquran pun banyak mengecam kebiasaan mereka (QS. alTakātsur[102]: 1-2) (QS.al-Humazah [104]: 17):

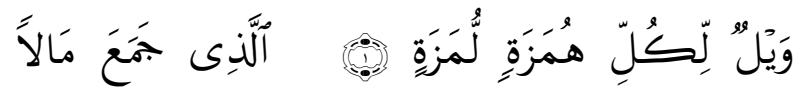

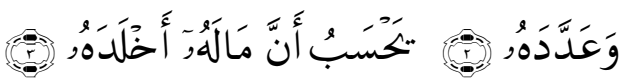

Kecelakaanlah bagi setiap pengumpat lagi pencela, yang mengumpulkan harta dan menghitung-hitungnya, dia mengira bahwa hartanya itu dapat mengekalkannya"(QS.Al-Humāzah [104]: 1-3)

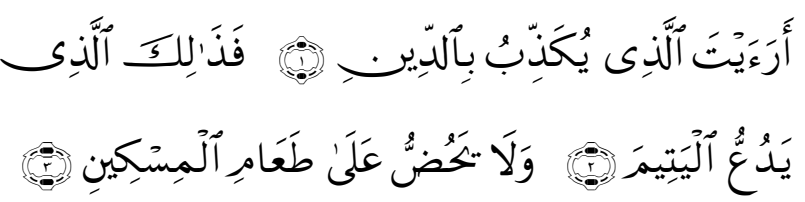

Tahukah kamu (orang) yang mendustakan agama? Itulah orang yang menghardik anak yatim, dan tidak menganjurkan memberi makan orang miskin.(QS. AlMà'ūn [107]: 1-3)

Kemudian Alquran memberikan arahanarahan tentang bagaimana bersikap terhadap orang-orang yang lemah dengan menganjurkan untuk mengasihi anak yatim, memperhatikan fakir miskin dan menolong orang-orang yang tertindas dengan memberikan zakat dan sedekah bagi mereka. Seperti dalam surat al-Tawbah ayat 60:
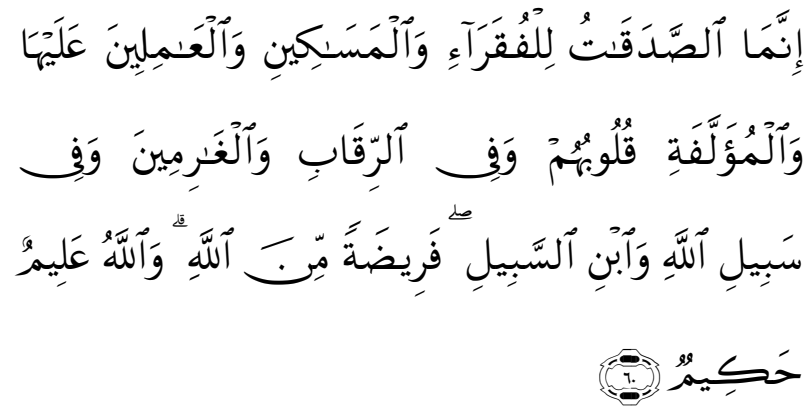

Sesungguhnya zakat-zakat itu, hanyalah untuk orang-orang fakir, orang-orang miskin, pengurus-pengurus zakat, para mu'allaf yang dibujuk hatinya, untuk (memerdekakan) budak, orang-orang yang berhutang, untuk jalan Allah dan untuk mereka yuang sedang dalam perjalanan, sebagai suatu ketetapan yang diwajibkan Allah, dan Allah Maha Mengetahui lagi Maha Bijaksana. (QS. Al-Tawbah [9]: 60)

Islam mengajarkan hidup bermasyarakat berdasarkan persamaan dan persaudaraan. Saling tolong menolong dalam kebajikan dan menghilangkan sifat dendam. Menghilangkan perbedaan-perbedaan dan ashabiyyah antar kabilah masing-masing. Ajaran-ajaran ini tentu saja mendapat tentangan dari orangorang yang merasa terancam keberadaannya oleh misi Nabi tersebut.

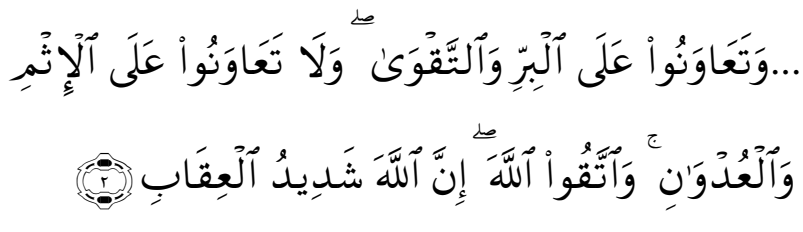

Dan tolong-menolonglah kamu dalam (mengerjakan) kebajikan dan takwa, dan jangan tolong-menolong dalam berbuat dosa dan pelanggaran. Dan bertakwalah kamu kepada Allah, sesungguhnya Allah amat berat siksa-Nya.(QS. Al-Māidah [5]: 2).

Allah telah mengantisipasi terhadap kecaman-kecaman yang ditimbulkan oleh para penentang misi Nabi tersebut. Ayat-ayat tentang peringatan bagi orang-orang yang menyangkal dan meragukan ajaran-ajaran Muhammadbanyak muncul pada awal masa Islam. Peringatan akan kebiasaan yang selama ini mereka lakukan dengan penggambaran adzab dan siksa neraka di akhirat kelak (QS. Al-'Alā[87]: 12-13).

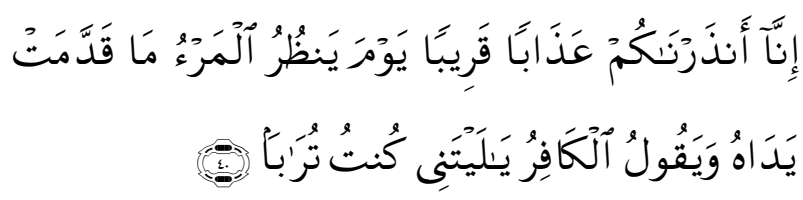


Sesungguhnya Kami telah memperingatkan kepadamu (hai orang kafir) siksa yang dekat, pada hari manusia melihat apa yang telah diperbuat oleh kedua tangannya; dan orang kafir berkata: "Alangkah baiknya sekiranya aku dahulu adalah tanah". (QS. Al-Nabā [78]: 40).

Pemberian peringatan ini diperlukan untuk menyadarkan manusia akan pertanggungjawaban amal perbuatannya kepada Allah di akhirat. Peringatan ini juga berguna agar manusia dapat memperbaiki prilakunya sedini mungkin sebelum terlambat.

Di samping memberikan peringatan, Islam juga memberikan "prize" terhadap para pengikut ajaran-ajaran Nabi berupa berita gembira tentang pahala yang besar, kemuliaan hidup serta surga yang kekal. Kabar gembira ini biasanya ditunjukan bagi orang-orang yang takwa, orang mukmin dan orang saleh (QS. [19]: 97, [17]: 9, [10]: 2). Hal ini sesuai dengan tugas Nabi itu sendiri sebagai pemberi peringatan dan pembawa kabar gembira (QS. [2]: 119, [25]: 1).

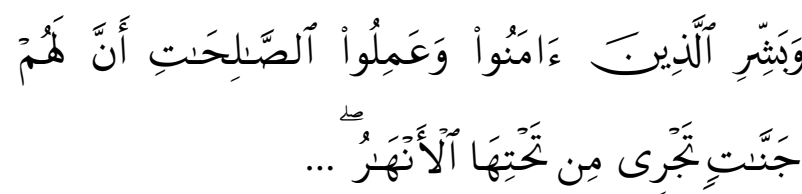

Dan sampaikanlah berita gembira kepada mereka yang beriman dan berbuat baik, bahwa bagi mereka disediakan surgasurga yang mengalir sungai-sungai di dalamnya.(QS. al-Baqarah [2]: 25).

Sementara periode Madinah (kedua) adalah periode perkembangan sosial kemasyarakatan karena pada periode ini sudah termasuk periode kestabilan sosial. Pada periode ini mulai dibuat hukum-hukum syari'at dan perundang-undangan masyarakat seperti hukum keluarga dan perkawinan (QS. [4]: 22, 23, dan 24), tata cara mu'amalah (QS. [2]: 275 dan 282), hubungan antar sesama muslim (QS. [49]: 11), antara Muslim dan non-Muslim (QS. [5]: 51), dengan tujuan untuk melindungi masyarakat dari penyimpangan-penympangan dan dari orang-orang yang menyimpang.
Perjuangan Nabi tersebut terus berlangsung sampai kemudian mampu membangun sebuah masyarakat yang kokoh dengan berlandaskan Alquran yang mengatur segala aspek kehidupan (keagamaan, sosial, politik dan lain sebagainya). Setelah Nabi Saw. wafat, perjalanan sejarah ini terus dilanjutkan dan dipertahankan oleh para sahabatnya dan kemudian seringkali terdapat hambatanhambatan dan penyimpangan, namun Alquran tetap dijadikan sebagai pedoman.

\section{SIMPULAN}

Dari pemaparan di atas, dapat dilihat bahwa telah terjadi dialog yang terus menerus antara teks Alquran dengan realitas yang ada. Teks tidak dapat membangun peradaban, yang membangun peradaban adalah interaksi dan dialektika antar teks, manusia dan realitas dengan segala unsur yang ada didalamnya (sosial, politik, ekonomi, budaya). Dan Alquran telah membangun sebuah peradaban yang kokoh secara bertahap karena interaksi yang serasi antar teks Alquran dengan realitas yang ada. ${ }^{16}$ Alquran, walaupun kita ketahui sebagai teks kebahasaan, namun ia tidak mengandung dan mewakili rangkaian hurufhuruf atau kata-kata semata, tetapi di dalamnya ia juga mewakili seluruh realitas yang ada.

Dengan demikian, memisahkan teks dari realitasnya sama dengan mengingkari kehidupan manusia kapanpun dan dimanapun ia berada, karena kekacauan-kekacauan yang terjadi di masyarakat serta ketimpanganketimpangan sosial akan terus ada selama manusia ada. Pesan dasar diturunkannya Alquran adalah membawa pencerahan yang membebaskan dan berkeadilan bagi penganutnya dan bukan kesusahan. Masyarakat Muslim sekarang perlu berkaca kepada sejarah awal Alquran diturunkan dengan semua kompleksitas permasalahan yang ada agar lebih bijak dalam memberikan arahan yang dilandaskan dari ajaran utama Islam ini. Pada kenyataannya, teks (Alquran)

${ }^{16} \mathrm{Abu}$ Zayd, Nashr Hamīd. Mafhūm al-Nash: Dirāsah fí 'Ulūm al-Qur'ān.(Mesir: Al-Hai'ah alMishriyyah al-Āmah al-Kitāb, 1993), 30. 
dan realitas tidak bisa dipisahkan, keduanya saling terkait satu sama lain dan saling mengkritisi secara terus-menerus.

\section{DAFTAR PUSTAKA}

Abu Zayd, Nashr Hamid. Mafhum al-Nash: Dirasah fi 'Ulum al-Qur'an. Mesir: AlHai'ah al-Mishriyyah al-Amah al-Kitab, 1993.

Al-Ghazali, Muhammad. Fiqh Sirah. Kairo: Matba'ah Hasan, 1988.

Amin, Ahmad. Fajr al-Islam.Beirut: Dar alFikr, tt..

Brockelman, Carl. History of Islamic People. New York: G.P. Putnam's Son, 1944.

Haikal, Muhammad Husen. Sejarah Hidup Muhammad, Jakarta: Tintamas, 1984.

Hitti, Philip K. History of the Arab.New York: Macmillan Student, 1970.
Ibnu Katsir. Al-Sirah Al-Nabawiyyah. Beirut: Dar al-Fikr, 1990.

Lapidus, Ira. History of The Islamic Society.New York: Cambridge University Press, 1993.

Raharjo, Dawam. "Sepatah Kata tentang Sejarah Muhammad", dalam Sirah Muhammad Rasulullah: Suatu Penafsiran. H. Fuad Hashem. Bandung: Mizan, 1996.

Rahman, Fazlur. Islam, terj. Ahsin Muhammad . Bandung: Pustaka, 1994.

Tema-tema Pokok al-

Qur'an, terj. Anas Mahyudin. Bandung: Pustaka, 1996.

Watt, Montgomery. Muhammad's Mecca: History in the Quran.London: Edinburgh University Press, 1982. 